\title{
SEROPREVALENCE OF LEISHMANIASIS, TOXOPLASMOSIS, AND LEPTOSPIROSIS IN THE DOMESTIC FAUNA OF AN ANTHROPIZED ENVIRONMENT OF THE ATLANTIC FOREST IN THE CITY OF RIO DE JANEIRO
}

\author{
(Soroprevalência de leishmaniose, toxoplasmose e leptospirose na fauna \\ doméstica, em ambiente antropizado da Mata Atlântica no município do Rio de \\ Janeiro)
}

Renato Orsini Ornellas ${ }^{1}$, Carlos José de Lima Barbosa Filho ${ }^{2}$, Daniela Duarte Alves de Albuquerque ${ }^{2}$, José Luís Passos Cordeiro ${ }^{2}$, Isabella Dib Ferreira Gremião ${ }^{1}$, Sandro Antônio Pereira ${ }^{1}$, Hélio Langoni ${ }^{4}$, Joelene Rosa dos Santos ${ }^{3}$, Vinícius Silva Belo ${ }^{4}$, Fabiano Borges Figueiredo ${ }^{5}$

\footnotetext{
${ }^{1}$ Fundação Oswaldo Cruz, Instituto Nacional de Infectologia Evandro Chagas, Laboratório de Pesquisa Clínica em Dermatozoonoses em Animais Domésticos, Rio de Janeiro, RJ, Brasil

${ }^{2}$ Fundação Oswaldo Cruz, Campus Fiocruz Mata Atlântica (CFMA), Rio de Janeiro, RJ, Brasil,

${ }^{3}$ Universidade Estadual Paulista Júlio de Mesquita Filho, Faculdade de Medicina Veterinária e Zootecnia de Botucatu, Departamento de Higiene Veterinária e Saúde Pública, Botucatu, São Paulo, Brasil, ${ }^{4}$ Universidade Federal de São João del-Rei, Campus Centro Oeste Dona Lindu, Divinópolis, Minas Gerais, Brasil, ${ }^{5}$ Fundação Oswaldo Cruz, Instituto Carlos Chagas, Laboratório de Biologia Celular, Curitiba, Paraná, Brasil
}

Corresponding author: renatoorsini@yahoo.com.br

ABSTRACT: The Fiocruz Mata Atlântica Campus (CFMA) represents one of the main urban growth fronts in Rio de Janeiro city. The present study evaluates the environment associated with the seroprevalence of canine visceral leishmaniasis (CVL), toxoplasmosis and leptospirosis in dogs and of toxoplasmosis in cats and production poultry belonging to the residents of the CFMA. Blood samples obtained by the census were used to assess frequency of positivity through serological assays. The proportion of seroprevalence of toxoplasmosis, leptospirosis and CVL were respectively $37.2 \%, 6.2 \%$ and $1.2 \%$. The association with the environment had different results depending on the infection. Seroprevalence of leptospirosis was significantly lower $(P=0.03)$ in dogs from anthropized areas $(3 \%)$, but this was the only region with cases of leishmaniasis. For toxoplasmosis, there was a higher seroprevalence $(50 \%)$ in rural scenarios. In cats, the seroprevalence of toxoplasmosis was $32.1 \%$ and in poultry, it was $18.1 \%$. The seroprevalence in these animals were similar in the studied environments. The results demonstrate the occurrence of Leishmania sp., Toxoplasma gondii and Leptospira spp. in dogs, cats, hens and ducks living in anthropic environments of the Atlantic Forest, in Rio de Janeiro city, being possible to correlate this occurrence between these domestic animal species and the living environment.

Keywords: Domestic animals; Leishmania spp.; Leptospira sp.; Toxoplasma gondii; zoonoses.

RESUMO: O Campus da Fiocruz Mata Atlântica (CFMA) representa uma das principais frentes de crescimento urbano da cidade do Rio de Janeiro. O presente estudo avalia o ambiente associado à soroprevalência de leishmaniose visceral canina (LVC), toxoplasmose e leptospirose em cães e de toxoplasmose em gatos e aves de produção pertencentes aos moradores do CFMA. Amostras de sangue obtidas pelo censo foram utilizadas para avaliar a frequência de prevalência através 
de ensaios sorológicos. A proporção de soroprevalência de toxoplasmose, leptospirose e LVC em cães foi de $37,2 \%, 6,2 \%$ e $1,2 \%$, respectivamente. A soroprevalência de leptospirose foi significativamente menor $(P=0,03)$ em cães de áreas antropizadas (3\%), mas essa foi a única região com casos de leishmaniose. Para toxoplasmose, houve maior soroprevalência $(50 \%)$ em cenários rurais. Nos gatos, a soroprevalência de toxoplasmose foi de $32,1 \%$ e em aves foi de $18,1 \%$. A soroprevalência nesses animais foi semelhante nos ambientes estudados. Os resultados demonstram a soroprevalência de Leishmania sp., Toxoplasma gondii e Leptospira spp. em cães, gatos, galinhas e patos residentes em ambientes antropizados da Mata Atlântica, no município do Rio de Janeiro, sendo possível, ainda, associar os resultados entre essas espécies de animais domésticos e o ambiente de moradia.

Palavras-chave: Animais domésticos; Leptospira sp.; Leishmania spp.; Toxoplasma gondii; zoonoses. 


\section{INTRODUCTION}

Human and animal health have always been interconnected, however, in recent years the contact among humans, domestic and wild animals has intensified, which facilitated the spread of infectious and parasitic agents to new hosts and the environment, resulting in the emergence of emerging or reemerging zoonoses, like leishmaniasis, toxoplasmosis, and leptospirosis (Gebreyes et. al. 2014). Emergence and re-emergence of zoonoses and recognition of the One Health concept by international agencies make research on the relationship between environment, human health and animal health a priority in different contexts (Gibbs, 2014).

The Campus Fiocruz Mata Atlântica (CFMA), with $80 \%$ of its area still forested, is located on the border between the natural and anthropic ecosystems, and is classically an area with suitable conditions to the emergence of diseases, especially zoonoses. The present study determined the occurrence with infection by leishmaniasis, toxoplasmosis, and leptospirosis in dogs, in addition to the occurrence of toxoplasmosis in cats, hens, and ducks living in the anthropized environment of the CFMA. This analysis enables better understanding of the occurrence of these infections and their association with the environment, providing subsidies for a better control of these zoonoses in transitional environments between natural and anthropized ecosystems.

\section{MATERIALS AND METHODS}

This cross-sectional study was conducted between August 2012 and December 2014. Of the 220 residences located in the area, 90 had domestic animals. A census survey was performed through door-to-door active search, where blood samples from the animals were collected for serological evaluation.

Communities in the surroundings of the CFMA (Figure 1) and their environment were classified according characteristics as follows: i) urban environment (Sampaio Correia): houses located in asphalted streets in the border area between Colônia neighborhood and CFMA, with treated water and sewage pipeline; (ii) anthropized environment (Viana do Castelo, Faixa Azul and Nossa Senhora dos Remédios): houses located in unpaved streets in the forest border area; (iii) rural environment (Fincão): houses located near the forest and the areas used for growing fruits and vegetables and raising animals.

After a written consent form was signed by the legal-age animal owners, blood samples were collected from the animals by the puncture of the jugular vein (dogs and cats) and alar vein (birds). The material was centrifuged to obtain the serum, which was stored at $20{ }^{\circ} \mathrm{C}$ in microtubes until processing. All activities were approved by the Ethics Committee on Animal Use CEUA/Fiocruz.

For screening serodiagnosis of CVL (Canine Visceral Leishmaniasis), the Dual-path Platform chromatographic immunoassay (DPP® CVL rapid test) produced by Bio-Manguinhos $₫$ (Fiocruz; Rio de Janeiro) was performed according to the manufacturer's protocol. EIE-leishmaniose-visceralcanina-Biomanguinhos $\AA \quad$ (EIE-LVC) kit was used to confirm the diagnosis of positive cases according to the manufacturer's protocol.

For the diagnosis of toxoplasmosis in dogs and cats, serum samples were tested for anti- $T$. gondii through the Indirect Immunofluorescence Reaction (RIFI) performed according to Camargo (1974). The sera were diluted in $0.01 \mathrm{M}$ phosphate buffered saline $\mathrm{pH} 7.2$, from the $1: 16$ dilution to the $1: 4096$ dilution 
(Langoni et al., 2011). For diagnosis of toxoplasmosis in chickens and ducks, a modified Microscopic Agglutination Test (MAT) was used according to Desmonts and Remington (1980). Titers ranged from $1: 16$ to $1: 1024$.

For diagnosis of leptospirosis, serum samples were tested for antiLeptospira sp. antibodies using the Microscopic Agglutination Test (MAT) with cut-off point at 1:100 serum/antigen dilution according to the Leptospirosis
Manual of the Brazilian Ministry of Health (Brasil, 1995). A battery of live antigens comprising 13 serovars (Australis Autumnlis, Bratislava, Canícola, Cynopteri, Copenhageni, Icterohaemorragiae, Hardjo, Djasman, Grippotyphosa, Pomona, Pyrogenes, and Nupezo - 1) was used, maintained at $28^{\circ} \mathrm{C}$, and peaked weekly in Ellinghausen-McCullough-Johnson Harris (EMJH) medium (DIFCO Laboratories $\AA$, Detroit, USA).

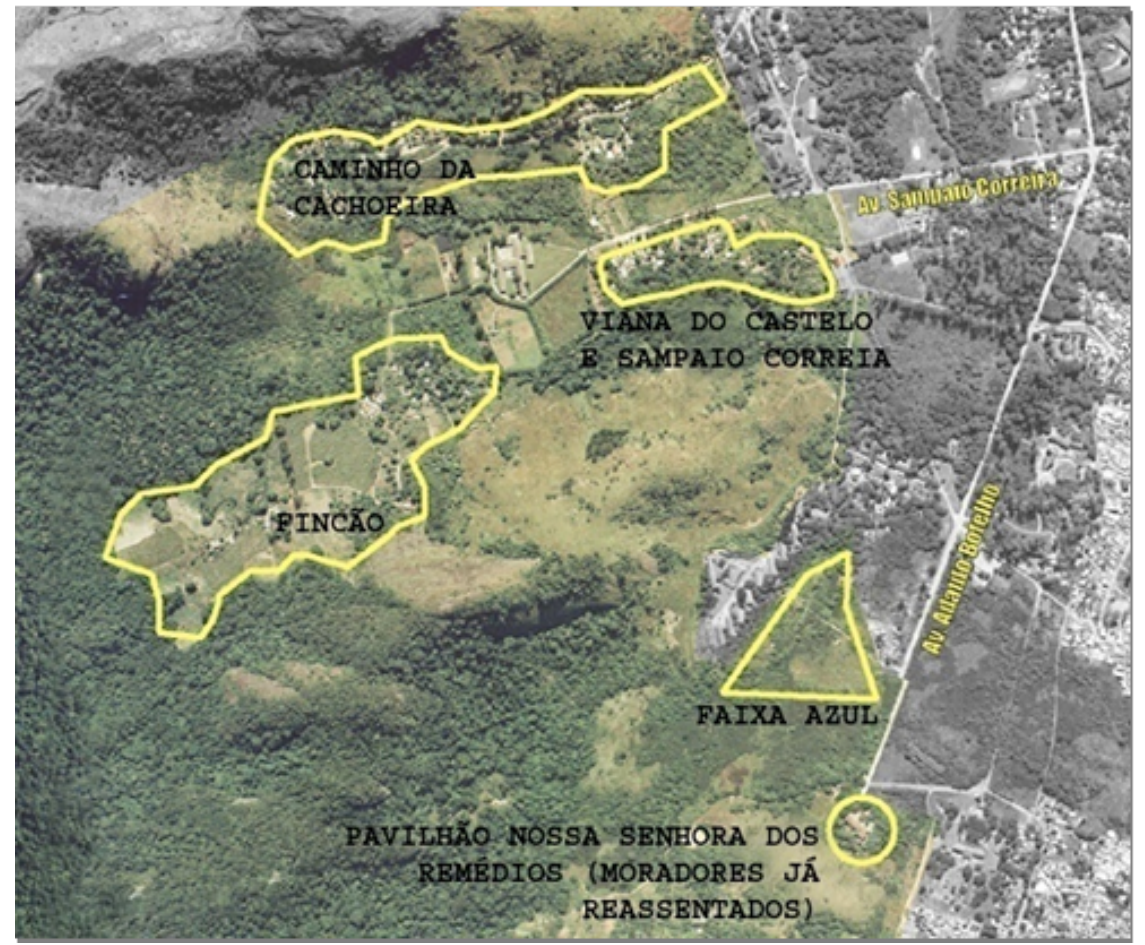

Figure 1. Communities of the Campus FIOCRUZ Mata Atlântica (CFMA) - Source: PICFMA, 2009.

Seroprevalence of $T$. gondii and Leptospira sp. in dogs was compared according to the living environment. In cats, only seroprevalence of $T$. gondii was compared. As for poultry, seroprevalence of $T$. gondii was compared in relation to the living environment and species. As there were only two cases of CVL, no statistical analyses were conducted relative to this condition. The statistical analyses were performed with application of the Chisquared test, or Fisher's exact test. A significance level of $5 \%$ was used in both situations. All procedures were processed using the Statistical Package for the Social Science (SPSS) 16.0 software.

\section{RESULTS}

Blood samples were collected from 161 dogs, 53 cats, 49 chickens, and 6 ducks. Table 1 shows the results obtained from the serological assays of dogs for CVL, toxoplasmosis, and leptospirosis infections. 
Table 1. Results of serological assays performed in dogs from the CFMA - 2012-2014.

\begin{tabular}{|c|c|c|c|c|c|c|c|c|c|c|c|c|}
\hline \multicolumn{5}{|c|}{$\mathrm{DPP}^{1} / \mathrm{ELISA}^{2}$ (Leishmaniasis $-\mathrm{CVL}^{3}$ ) } & \multicolumn{4}{|c|}{ IFR $^{4}$ (Toxoplasmosis) } & \multicolumn{4}{|c|}{ MAT $^{5}$ (Leptospirosis) } \\
\hline & Positive & $\%$ & Negative & $\%$ & Positive & $\%$ & Negative & $\%$ & Positive & $\%$ & Negative & $\%$ \\
\hline Urbanized & 0 & 0 & 23 & 100 & 6 & 26.1 & 17 & 73,9 & 3 & 13.0 & 20 & 87.0 \\
\hline Rural & 0 & 0 & 30 & 100 & 15 & 50.0 & 15 & 50.0 & 4 & 13.3 & 26 & 86.7 \\
\hline Anthropized & 2 & 1.9 & 106 & 98.1 & 39 & 36,1 & 69 & 63.9 & 3 & 2.8 & 105 & 97.2 \\
\hline Total & 2 & 1.9 & 159 & 98.1 & 60 & 37.3 & 101 & 62.7 & 10 & 6.2 & 151 & 93.8 \\
\hline
\end{tabular}

Captions: 1=Dual Path Platform (DPP ${ }^{\Theta}$ ) Immunoassay; 2=Enzyme-Linked Immunosorbent Assay; 3=Canine Visceral Leishmaniasis; 4=Indirect Immunofluorescence Reaction; 5=Microscopic Agglutination Test

The seroprevalence of leptospirosis was significantly lower $(\mathrm{P}$ value $=0,034545$ ) in dogs from anthropized areas. As for distribution by serovars, there was a predominance of seroreactivity for the Grippotyphosa sample, with seven $(4.35 \%)$ reactive animals, followed by Copenhageni, which presented four $(2.48 \%)$ reactive animals and Pomona, with one $(0.62 \%)$ reactive animal. Two animals showed reactivity for two serovars: one showed reactivity for Grippotyphosa and Copenhageni serovars, and the other one showed reactivity for Grippotyphosa and Pomona serovars. No sample showed seroreactivity for other tested serovars. None of the dogs showed clinical signs. With respect to $T$. gondii reactivity, rural areas had a higher occurrence, although in a not statistically significant way $(P=0,18)$. Only two cases of leishmaniasis were identified, both in the anthropized area. All dogs and cats in the study were only vaccinated against the rabies virus in public campaigns carried out in the Rio de Janeiro city.

Table 2. Results of serological tests for $T$. gondii performed in cats and poultry of the CFMA - 2012-2014

\begin{tabular}{lcccccccc}
\hline & \multicolumn{3}{c}{ IFR $^{1}$ (Cats) } & \multicolumn{4}{c}{ MAT $^{2}$ (Poultry) } \\
\cline { 2 - 9 } & Positive & $\%$ & Negative & $\%$ & Positive & $\%$ & Negative & $\%$ \\
\hline Urbanized & 2 & 28.6 & 5 & 71.4 & 0 & 0 & 0 & 0 \\
Rural & 3 & 33.3 & 6 & 66.7 & 8 & 17.8 & 37 & 82,2 \\
Anthropized & 12 & 32.4 & 25 & 67.6 & 2 & 20.0 & 8 & 80,0 \\
Total & 17 & 32.1 & 36 & 67.9 & 10 & 18.2 & 45 & 81.8 \\
\hline
\end{tabular}

Captions: 1 =Indirect Immunofluorescence Reaction; 2 =Microscopic Agglutination Test.

\section{DISCUSSION}

The two dogs (1.9\%), which tested positive in the DPP ${ }^{\circledR}$ for CVL, had been abandoned at the CFMA according to residents. Souza et al. (2015) reported the presence at low dispersion of the main CVL vector, Lutzomyia longipalpis, in the peridomicile region of CFMA. The coexistence between seropositive dogs and vectors becomes a potential risk of disease spread (Figueiredo et al. 2012).

Six dogs $(26.1 \%)$ positive for toxoplasmosis were found in the urbanized area of the CFMA, thus indicating a high occurrence of $T$. gondii in this environment. Others studies (Costa et al. 2013; Caldart et al. 2015) showed results close to that obtained in our survey study. 
In rural areas, 15 animals (50\%) were positive for toxoplasmosis, showing that, in this region, $T$. gondii occurrence is higher. In a study carried out in the rural area of Cuiabá (MT), Boa Sorte et al. (2015) reported occurrence of $62.4 \%$ for $T$. gondii. The high occurrence of $T$. gondii in cats $(33.3 \%)$ in this region indicates a high environmental contamination, explaining the high occurrence in dogs. In addition, this region lacks basic sanitation, contributing to environmental contamination.

In the anthropized areas of CFMA the occurrence of toxoplasmosis was high, with 39 positive animals (36.1\%). This finding may be justified by the carnivorous practice of dogs hunting other animals in the forest; and also the high occurrence in the local cats, indicating environmental contamination by oocysts eliminated in your feces.

Analysis of the toxoplasmosis results in cats showed that 17 positive animals $(32.1 \%)$ were detected by IFR of a total of 53 animals throughout the CFMA area, with the highest positivity observed in the rural environment, followed by the anthropized and urban areas. This result indicates very intense environmental contamination, as some cats can eliminate approximately 360 million uncultured oocysts environment per day (Dubey, 2002). In the rural environment of the CFMA, three cats (33, 3\%) were seropositive for $T$. gondii. In this area, there is interaction between cats, production animals, birds and rodents, facilitating carnivorism by cats, which may explain the high positivity.

In the anthropized areas, positivity for toxoplasmosis in cats was $32.4 \%$ (12 animals). As the cats in this area circulated and hunted other animals through in the forest, this value was expected to be high.

In the urban area, two cats $(28.6 \%)$ tested positive for $T$. gondii. This result is similar to that observed by Netto et al.
(2003), who obtained positivity to $T$. gondii in eight $(19.51 \%)$ cats from Niteroi (RJ) using the Indirect Hemagglutination Test. The high occurrence observed in the urbanized environment of the CFMA was not expected, since cats in this area do not transit outdoors and feed on commercial food, unlike research conducted in Niterói, where cats had access to the street and were able to practice hunting for food.

As for Leptospira sp. reactivity in dogs, $10(6.2 \%)$ out of 161 animals tested positive in the MAT. The occurrence of leptospirosis was significantly lower in dogs from anthropized areas, different from what was expected, since this is the CFMA region with more favorable social conditions for leptospirosis, such as poor basic sanitation, absence of regular garbage collection, presence of synanthropic and wild rodents and flooded areas after storms. Surprisingly, the rural environment was the CFMA region with the highest occurrence of leptospirosis, which has synanthropic rodents and irregular garbage collection. The CFMA urban area presented three dogs (13\%) positive for Leptospira sp., which may have occurred due to the fact that many dogs adopted from other regions of CFMA, might have been infected before adoption. Regarding the frequency of serovars, there was a predominance of serovar Grippotyphosa. This data differs from the studies by Favero et al. (2002) and Freire et al. (2007), who described Icterohaemorrhagiae and Copenhageni serovars as the most frequently found in serological surveys of canine samples without clinical suspicion. In addition, Grippotyphosa and Pomona serovars were no detected. Regarding toxoplasmosis, 10 out of 55 animals $(18.2 \%)$ of CFMA were positive by MAT, with greater positivity in rural area followed by the anthropized areas. Presence of poultry was not reported in 
the urban environment of the CFMA. Carsartelli-Alves et al. (2015), in a study on $T$. gondii in an endemic area of Rio de Janeiro state, observed 63 positive animals $(41.2 \%)$, by the technique of bioassay in rats, which is the standard method for diagnosis of $T$. gondii in birds (Dubey,2010). Perhaps the results of the studies were different for that reason.

Eight birds were positive $(17.8 \%)$ for $T$. gondii in the rural area of the CFMA. These birds were created extensively and with great interaction with local dogs and cats. CarsartelliAlves et al. (2012) investigated the occurrence of $T$. gondii in chickens reared extensively in Rio Bonito (RJ), and observed 61 seropositive animals (27.6\%), using IFR technique. The fact that MAT is nonspecific contributed to the different results between the studies, although they were not as discrepant. Two birds tested positive $(20.0 \%)$ for $T$. gondii in the anthropic areas of the CFMA. This finding corroborates the results of occurrence of positive dogs and cats in this area, which were $36.1 \%$ and $32.4 \%$, respectively, indicating high environmental contamination.

\section{CONCLUSION}

The present study demonstrated the occurrence the circulation of Leishmania sp., T. gondii and Leptospira sp. in the CFMA area. Taking into account that there is an integration among human, animal and environmental health, this result indicates the need for public policies in the practice of preventing diseases caused by these agents.

\section{ACKNOWLEDGMENTS}

Martha L. Brandão (CFMA Fiocruz); Adilson B. de Almeida (Lapclin Dermzoo / INI - Fiocruz); Dr. Valmir L. Silva (DCB/ ENSP - Fiocruz) And Artur
A. V. Mendes Jr (Lapclin Dermzoo / INI - Fiocruz).

The authors also thank the National Research and Development Council (CNPq) for the scholarship granted to Renato O. Ornellas during the master's degree. This study was supported by FAPERJ (Grants: LCNE E26/201.495/2014 and GEP E26/110.109/2014). FBF hold grants from CNPq for productivity in research.

\section{INFORMATION NOTES}

Ethics Committee on Animal Use CEUA/Fiocruz: LW 60/14 (Carina moschata); LW 22/15 (Gallus gallus domesticus); LW 7/15 (Canis familiaris); LW 9/15 (Feliz sylvestris catus).

\section{REFERENCES}

BOA SORTE, E. C.; ALMEIDA, A.B.P.; CRUZ, F.A.C.S. et al. Detecção sorológica e molecular de Toxoplasma gondii em cães de áreas urbanas e rurais de Cuiabá, Mato Grosso. Semina: Ciências Agrárias. v. 36, n. 1, p. 3705 - 3712, 2015.

BRASIL. Manual de Leptospirose. 2nd ed. Brasília: Fundação Nacional de Saúde. Ministério da Saúde; 1995.

CALDART, E.T.; CONSTANTINO, C.; PASQUALI, A.K.S. et al. Zoonoses em cães e gatos atendidos em projeto de controle de natalidade: Toxoplasma gondii, Leishmania spp., sorodiagnóstico e epidemiologia. Semina: Ciências Agrárias, v.36, n. 1, p. 253 - 266, 2015.

CAMARGO, M. Introdução às técnicas de imunofluorescência. Revista Brasileira de Patologia Clínica. v. 10, n. 3 , p. $87-107,1974$

CASAETELLI-ALVES, L.; FERREIRA, L.C.; VICENTE, R.T. et al. Prevalência da infecção por Toxoplasma gondii em galinhas criadas extensivamente em Rio Bonito, Rio de Janeiro. Arquivo 
Brasileiro de Medicina Veterinária e Zootecnia, v. 64 , n. 5, p. $1398-1401$, 2012.

CASARTELLI-ALVES, AMENDOEIRA, M.R.R.; BOECHAT, V.C. et al. Mapping of the environmental contamination of Toxoplasma gondii by georeferencing isolates from chickens in an endemic area in Southeast Rio de Janeiro State, Brazil. Geospatial Health, v. 10, n. 311, p. $20-25,2015$.

COSTA, V.M.; SILVA, R.C.; BRANTI, J.L. et al. Prevalência e distribuição geográfica do Toxoplasma gondii em cães na área urbana de Botucatu, SP, Brazil. Brazilian Journal of Veterinary Research and Animal Science, São Paulo, v. 50, n. 2, p. $152-155,2013$.

DESMONTS, G.; REMINGTON, J.S. Direct agglutination test for diagnosis of Toxoplasma infection: method for increasing sensitivity and specificity. Journal of Clinical Microbiology, v. 11,n. 6, p. 562-568, 1980.

DUBEY, J.P. Tachyzoite-induced life cycle of Toxoplasma gondii in cats. Journal of Parasitology, v. 88, n. 4, p. 713-717, 2002.

DUBEY, J.P. Toxoplasma gondii infections in chickens (Gallus domesticus): prevalence, clinical disease, diagnosis and public health significance. Zoonoses and Public Health, v. 57, n. 1, p. 60-73, 2010.

FAVERO, A.C.M.; PINHEIRO, S.R.; VASCONCELLOS, S.A. et al. Sorovares de leptospiras predominantes em exames sorológicos de bubalinos, ovinos, caprinos, equinos, suínos e cães de diversos estados brasileiros. Revista Ciência Rural, v. 32, n. 4, p. 613-619, 2002.

FIGUEIREDO, F.B.; LIMA JR., F.E.F.; TOMIO, J.E. et al. Leishmaniose Visceral Canina: Dois casos autóctones no município de Florianópolis, estado de
Santa Catarina. Acta Scientiae Veterinariae, v. 40, p. 1026-9, 2012.

FREIRE, I.M.A.; VARGES, R. G.; GOMES, Y.N.P. et al. Distribuição dos serovares de leptospira em caninos clinicamente suspeitos no Rio de Janeiro. Revista Brasileira de Ciências Veterinárias, v. 14, n. 2, p. 83-85, 2007.

GEBREYES, W.A.; DUPOUY-CAMET, J.; NEWPORT, M.J. et. al. The global one health paradigm: challenges and opportunities for tackinling infectious diseases at the human, animal, and environment interface in low-resource settings. Plos Neglected Diseases, $v$. 8, n. 11, p. 1-6, 2014.

GIBBS, E.P.J. The evolution of One Health: a decade of progress and challenges for the future. Veterinary Record, v. 174, n. 4, p. 85-91, 2014.

LANGONI, H.; GRECA, H.JR.; GUIMARÃES, F.F. et al. Serological profile of Toxoplasma gondii and Neospora caninum infection in commercial sheep from São Paulo State, Brazil. Veterinary Parasitology, v. 177, n. 1, p. 50-54, 2011.

NETTO, E. G.; MUNHOZ, A.D.; ALBUQUERQUE, G.R. et al. Ocorrência de gatos soropositivos para Toxoplasma gondii Nicolle e Manceaux, 1909 (Apicomplexa: Toxoplasmatinae) na cidade de Niterói, Rio de Janeiro. Revista Brasileira de Parasitologia Veterinária, v. 12 , n. 4 , p. 145-149, 2003.

SOUZA, N. A.; SILVA, J.B.; GODOY, R.E. et al. Studies on Phlebotominae (Diptera: Psychodidae) in the Campus Fiocruz Mata Atlântica, Jacarepaguá, in the City of Rio de Janeiro, Brazil. Revevista da Sociedade Brasileira de Medicina Tropical, v. 48 , n. 1 , p. $26-$ 32, 2015. 